\title{
Innovation Development of Coffee Berry Borrer (Hypothenemus hampei Ferr.) Pest Control Technology and Their Effectiveness
}

\author{
Siska Rasiska* \\ ${ }^{1}$ Departement of Plant Pests and Diseases, Agriculture Faculty, Universitas Padjadjaran, Jatinangor, West Java 45363 \\ *Corresponding Author : s.rasiska@unpad.ac.id
}

Received October 27, 2021; revised January 13, 2022; accepted January 17, 2022

\begin{abstract}
The Coffee Berry Borer (CBB) (Hypothenemus hampei Ferrari)(Coleoptera:Curculionidae:Scolytinae) is a major pest of coffee plants. It caused damage to coffee berries and economic losses for farmers. Various technologies have been carried out to control CBB, including cultural biological, chemical, and sanitation. However, of the technology control of CBB, only a few literature that discussed the effectiveness and efficiency, both socially, economically and their impact on the environment. Thus, this paper aimed to: 1) review research CBB control technology based on characteristics; and 2) assessing the effectiveness and efficiency of the technology in controlling CBB based on compatibility, applicability, availability, safety, sustainability, affordability and economic. This study was conducted using a systematic review of the literature from the search engine Science.direct, Google.scholar, which was identified from 1996 to 2020. The search resulted showed that there were 59 articles related to CBB control technology and were divided into several types, namely 22 articles that discuss technology in cultural, 31 articles that discuss biological control, 5 articles that discuss technology chemically, and 1 articles that discusses orchard sanitation technology. CBB control technologies that are considered to have compatibility, safety, sustainability, affordability and economic are cultural, biological control and sanitation. However, if it is related to applicability and availability, cultural and sanitation can be the main choice. Many studies on biological technology showing advantages compared to other technologies, thus, biological control technology as a preventive and monitoring effort is still being developed. One of them is developing biological technology with a landscape approach.
\end{abstract}

Keywords: cultural, biological control, chemical, sanitation, landscape approach

\section{ABSTRAK}

\section{Perkembangan Inovasi Teknologi Pengelolaan Hama Penggerek Buah Kopi (Hypothenemus hampei Ferr.) (Coleoptera: Curculionidae: Scotylidae) dan Keefektifannya}

Penggerek Buah Kopi (Hypothenemus hampei Ferrari) (Coleoptera:Curculionidae:Scolytinae) merupakan hama utama tanaman kopi, yang telah menyebabkan kerusakan pada buah kopi dan kerugian secara ekonomi bagi petani. Berbagai teknologi telah dilakukan untuk mengendalikan hama PBKo, di antaranya secara kultur teknis, biologis, kimiawi dan sanitasi pada saat pascapanen. Namun, dari beberapa teknologi pengendalian tersebut, belum banyak penelitian yang membahas tentang keefektifan dan efisiensinya, baik secara sosial, ekonomi maupun pengaruhnya terhadap lingkungan. Dengan demikian, tulisan ini bertujuan untuk: 1) mereview penelitian tentang perkembangan teknologi pengendalian hama PBKo berdasarkan pada karakteristiknya; dan 2) menilai keefektifan dan efisiensi teknologi tersebut dalam mengendalikan hama PBKo berdasarkan indikator yaitu kesesuaian, penerapan, ketersediaan, keamanan, keberlanjutan, keterjangkauan dan ekonomis. Kajian ini dilakukan dengan menggunakan tinjauan sistematis terhadap literatur dari mesin pencarian Science.direct, Google.scholar, yang teridentifikasi sejak 1996 hingga 2020. Hasil penelusuran menunjukkan terdapat 59 artikel yang terkait dengan teknologi pengendalian hama PBKo dan dibagi ke dalam beberapa jenis, yaitu 22 artikel yang membahas tentang teknologi secara kultur teknis, 31 artikel yang membahas tentang teknologi secara biologis, 5 artikel yang membahas tentang teknologi secara kimiawi, dan 1 artikel yang membahas tentang teknologi sanitasi kebun. Teknologi pengendalian hama PBKo yang dianggap memiliki kesesuaian, keamanan, keberlanjutan, keterjangkauan dan ekonomis adalah kultur teknis, biologis dan sanitasi kebun. Akan tetapi, jika dikaitkan dengan penerapan dan ketersediaan, maka kultur teknis dan sanitasi kebun dapat menjadi pilihan utama. Namun, dengan banyaknya penelitian mengenai teknologi biologis menunjukkan adanya keunggulan dibandingkan dengan teknologi yang lain, Dengan demikian, teknologi pengendalian secara biologis sebagai upaya preventif dan monitoring masih dikembangkan inovasinya. Salah satunya mengembangkan teknologi biologis dengan pendekatan lanskap.

Kata Kunci: kultur teknis, biologis, kimiawi, sanitasi, pendekatan lanskap

\section{PENDAHULUAN}

Kopi arabika (Coffea arabica) merupakan salah satu tanaman tropis yang secara geografis dan geologis (Fain et al., 2018) sesuai ditanam di dataran tinggi dan menjadi tanaman pendamping di sistem agroforestry (Ferfecto \& Armbrecht, 2003). Secara ekologis, kombinasi tersebut memiliki berbagai fungsi atau layanan ekosistem, seperti menyediakan pangan, papan, mengatur siklus air dan iklim mikro, mencegah erosi, mendukung siklus nutrisi, dan menyediakan habitat bagi hewan liar (Ferfecto \& Armbrecht, 2003), serta secara kultural dapat mengedukasi dan rekreasi (DA Hayyun et al., 2018). Di dekat daerah aliran sungai, agroforestry kopi dan tanaman perhutanan 
juga berfungsi sebagai konservasi sumberdaya hayati, konservasi tanah dan air, dan menyimpan kandungan karbon di alam (Jezeer et al., 2019), yang secara simultan dapat meningkatkan kualitas kehidupan petani (Iverson et al., 2019). Secara ekonomi, permintaan ekspor kopi terus mengalami peningkatan dengan rata-rata $369.551,93$ ton per tahun, dan mengalami pertumbuhan sebesar $4,39 \%$ per tahun (Syakir dan Surmaini, 2017), dan telah menghasilkan devisa yang cukup besar bagi negara Indonesia dengan rata-rata 718.381,3 ribu US\$ per tahun (Badan Pusat Statistik, 2017), sehingga berkontribusi terhadap Pendapatan Domestik Bruto Indonesia hingga 10\% dari komoditas non-migas (Kementerian Pertanian Republik Indonesia, 2019).

Masalahnya, luas lahan dan produksi kopi cenderung mengalami penurunan (Direktorat Jenderal Perkebunan, 2017). Penurunan produksi kopi di Indonesia sekira $1 \%$ hingga $2 \%$ setiap tahunnya (Kementerian Pertanian, 2015). Apabila diidentifikasi, penurunan luas area kopi dan produksinya disebabkan oleh berbagai factor, seperti berkurangnya kesesuaian lahan untuk pertanaman kopi, serangan hama dan penyakit dan perubahan iklim (Syakir dan Surmaini, 2017). Penggerek Buah Kopi (Hypothenemus hampei Ferr.) (Coleoptera:Curculionidae:Scolytinae) merupakan hama utama pada tanaman kopi, terutama kopi arabika. PBKo telah menyebabkan kerusakan pada buah kopi dan kerugian bagi petani. Kerusakan yang disebabkan oleh PBKo dapat menurunkan produksi hingga $10-40 \%$ (Direktorat Jenderal Perkebunan, 2019). Berbagai teknologi pengendalian hama PBKo telah banyak dikembangkan hingga saat ini, yaitu secara kultur teknis, biologis, kimiawi, dan sanitasi pada saat pascapanen (Aristizabal, 2016; Escobar-Ramirez, 2019; Baker et al., 2019).

Pengendalian hama PBKo secara kimiawi dengan menggunakan pestisida sudah banyak dilakukan secara intensif di perkebunan kopi, seperti penggunaan bahan aktif ametryne, cyproconazole, diuron, epoxiconazole, flutriafol, triadimenol, triazophos, thiamethoxam, iprodione, endosulfan, pendimethalin, chlorpyrifos, copper II hydroxide, etion, epoxiconazole, paraquat dicloride dengan kategori berbahaya bagi lingkungan dan berpotensi membahayakan lingkungan, telah mengontaminasi sungai di daerah permukaan maupun di tanah (Robinson et al., 2002; Tebalde de Queiroz et al., 2018). Endosulfan yang mengandung lypophilic persistent organic juga dapat mendegradasi bakteri gram negatif di tanah, seperti Azotobacter sp dengan berkurangnya aktivitas nitrogenase, tetapi tidak memengaruhi produksi indole 3-acetic acid (Castillo et al., 2011). Akibat adanya dampak negatif dari penggunaan pestisida, maka pengendalian secara terpadu dan biologis (Jaramillo et al., 2006; Altieri et al., 2004) menjadi suatu pilihan yang tepat untuk mengendalikan hama tanaman kopi.

Pengendalian Hama secara Terpadu (PHT) merupakan pilihan yang tepat dalam upaya untuk mengurangi pestisida toksik dalam pertanian, untuk meningkatkan produktivitas agar diperoleh produk yang sehat dan menguntungkan, menyelamatkan tanaman dari kehilangan hasil akibat tekanan biotik serta meningkatkan produksi pertanian, kesehatan tanah, dan kesehatan lingkungan menjadi berkelanjutan (Baker et al., 2019). Akan tetapi dalam implementasinya, petani kesulitan untuk menerapkan PHT karena tidak tersedianya input PHT pada beberapa ukuran lahan, kompleksitas modul PHT untuk jenis tanaman yang berbeda, kurangnya informasi tentang efek senyawa toksik dan kurang berperannya penyuluh (Rao et al., 2015). PHT juga sulit untuk diterapkan terutama pada tanaman perkebunan yang bersifat tahunan karena ada beberapa kendala, seperti: (1) siklus perkembangan tanaman kopi yang relative panjang, dan multifungsi yang disediakan oleh hutan akan memengaruhi keputusan dalam menerapkan strategi proteksi; (2) ledakan hama tanaman kopi pada umumnya menyerang dapat mencapai puluhan bahkan ratusan hektar, sehingga metode proteksi yang diterapkan tidak tepat waktu, ledakan hama hanya dapat dikendalikan dengan melihat karakteristik epidemic pada jutaan hektar dari hutan yang terjadi secara regular (Tracey et al., 2014).

Penelitian mengenai teknologi pengendalian hama PBKo sudah banyak dilakukan, hanya dalam perkembangannya terdapat beberapa masalah, yaitu :1) belum adanya inovasi pengelolaan hama PBKo yang betul-betul efektif dan efisien; 2) inovasi teknologi yang diterapkan belum menghasilkan peningkatan produktivitas tanaman kopi; 3) penerapan inovasi teknologi pengelolaan hama PBKo belum rasional bagi petani kopi. Dengan demikian, perlu dilakukan kajian literatur mengenai perkembangan inovasi teknologi pengendalian hama PBKo yang efektif dan efisien, dapat meningkatkan produktivitas kopi dan rasional untuk diterapkan oleh petani. Tulisan ini bertujuan untuk: 1) meringkas penelitian tentang perkembangan teknologi pengendalian hama PBKo berdasarkan pada karakteristiknya; dan 2) menilai keefektifan dan efisiensi teknologi tersebut dalam mengendalikan hama PBKo berdasarkan indikator yaitu kesesuaian, penerapan, ketersediaan, keamanan, keberlanjutan, keterjangkauan dan ekonomis

\section{BAHAN DAN METODE}

Protokol penelusuran. Kajian ini dilakukan dengan menggunakan tinjauan terhadap literatur, berdasarkan mesin pencarian (searching machine) dari Science.direct, Google.scholar, yang teridentifikasi sejak tahun 1996 hingga 2020. String pencarian difokuskan pada teknologi kultur teknis, teknologi biologis, teknologi kimiawi dan teknologi pascapanen yang terkait dengan PBKo. String pencarian yang digunakan untuk menemukan tulisan tentang pengelolaan tanaman kopi dan PBKo adalah seperti yang disajikan pada Tabel 1 . 
Tabel 1. Teknik pencarian literatur dan string pencarian yang digunakan terkait dengan artikel tentang teknologi pengelolaan PBKo.

\begin{tabular}{|c|c|c|}
\hline Teknologi & Elemen Kajian & Kata kunci \\
\hline \multirow[t]{7}{*}{ Kultur Teknis } & Tradisional & “Agroforestry AND Coffee Berry Borer"OR \\
\hline & & "Shade cover AND Hypothenemus hampei"OR \\
\hline & Konvensional & "Fertilizer AND Coffee berry bore"OR \\
\hline & & "Pesticide AND Hypothenemus hampei"OR \\
\hline & & "Monoculture AND Coffee berry borer"OR \\
\hline & & “Unshade AND Hypothenemus hampei”OR \\
\hline & Organik & “Organic farming AND Coffee berry borer"OR \\
\hline \multirow[t]{6}{*}{ Biologis } & Semut & "Ant AND Coffee berry borer"OR \\
\hline & & “Ant AND Shade cover”OR \\
\hline & Burung & "Bird AND Hypothenemus hampei”OR \\
\hline & Tabuhan & $\begin{array}{l}\text { "Wasp AND Coffee berry bore"OR"Parasitoid AND Hypothenemus } \\
\text { hampei"OR"Hymenoptera parasitism AND Coffee berry borer"OR }\end{array}$ \\
\hline & Jamur & $\begin{array}{l}\text { "Beauveria bassiana And Coffee berry borer"OR"Metarrhizium And } \\
\text { Hypothenemus hampei"OR"Bacillus thuringiensis AND Coffee berry } \\
\text { borer"OR"Fungi AND Hypothenemus hampei"OR }\end{array}$ \\
\hline & Nematoda & "Steinernema coffea AND Coffee berry borer"OR" \\
\hline \multirow[t]{2}{*}{ Kimiawi } & Insektisida & "Endosulfan AND Coffee berry borer"OR"Cyantraniliprole \\
\hline & & $\begin{array}{l}\text { Hypothenemus hampei"OR"Pesticide AND } \\
\text { borer"OR"Insecticide AND Hypothenemus hampei"OR }\end{array}$ \\
\hline
\end{tabular}

Untuk mengukur kajian yang menguji pengendalian kultur teknis terhadap PBKo, maka dipilihlah kajian yang memiliki efek langsung terhadap PBKo, contohnya efek naungan terhadap kelimpahan PBKo, kemudian dilakukan pengklasifikasikan menurut taksonomi kelompok, seperti tentang kultur teknis, biologis, kimiawi dan pasca panen dan semua teknologi dilanjutkan dengan analisis berdasarkan indikator kesesuaian, penerapan, ketersediaan, keamanan, keberlanjutan, keterjangkauan dan ekonomis.

\section{HASIL DAN PEMBAHASAN}

\section{Teknologi Kultur Teknis}

Hasil penelusuran menunjukkan bahwa terdapat 22 artikel yang terkait dengan teknologi pengendalian PBKo secara kultur teknis. Teknologi pengendalian hama secara kultur teknis yang disebut juga sebagai strategi pengelolaan hama "bottom-up" merupakan taktik yang dilakukan untuk mendapatkan tanaman yang sehat secara optimal, yang praktiknya meliputi pengelolaan tanaman, pengelolaan habitat (tanah dan air), serta pengelolaan nutrisi, dalam upaya untuk mencegah semua tipe serangga hama, penyakit tanaman, gulma, nematoda, dan hama vertebrata pada tanaman secara terstruktur (Baker et al., 2019; Edosa et al., 2018). Praktek pengelolaan tanaman yang dilakukan oleh petani dibagi ke dalam tiga karakteristik, yaitu secara tradisional, konvensional dan organik (Tabel 2.).

Praktik pengelolaan tanaman yang dilakukan oleh petani akan memengaruhi pertumbuhan, perkembangan dan perilaku hama PBKo. Sayangnya, tidak ditemukan artikel mengenai pengelolaan tanaman kopi secara organik yang berpengaruh langsung terhadap hama PBKo, dan sebagian besar hanya terkait dengan kualitas dan kuantitas tanaman kopi. Namun, secara tidak langsung senyawa bioaktif yang terkandung di dalam buah kopi, seperti senyawa fenol dan flavonoid dipengaruhi oleh pengelolaan tanaman, dan pengelolaan tanaman kopi secara organik kandungan senyawa bioaktif dan aktivitas antioksidannya, DPPH (2,2-diphenyl-1-picryhydrazyl) dan ABTS )2,2'-azino-bis-3-ethylbenzthiazoline 6sulphonic-acid) lebih banyak konsentrasinya dibandingkan secara konvensional (Ozuna et al., 2020). Dan kandungan bioaktif pada buah kopi dapat memengaruhi perilaku dan metabolisme serangga hama PBKo.

Tabel 2. Kajian yang Terkait dengan Teknologi Kultur Tekni

\begin{tabular}{lll}
\hline \multicolumn{1}{c}{ Kelompok } & \multicolumn{1}{c}{ Elemen Kajian } & \multicolumn{1}{c}{ Penulis } \\
\hline Tradisional & Pohon naungan & Denu et al., 2017; Rahn et al. 2018; Tschora et al., 2019; Jezeer \\
Agroforestry $)$ & & et al., 2019; Nesper et al., 2017; Bosselmann et al, 2009; Richter \\
& & $\begin{array}{l}\text { et al., 2007; Sauvadet } \text { et al., 2019; Beilhe } \text { et al., 2020; Wang } \text { et } \\
\text { Kol., 2015; Soto-Pinto } \text { et al., 2002; Marino } \text { et al., 2015) }\end{array}$ \\
& & Simon-Gruita et al., 2019; Molina, Zamora \& Blanco-Labra, 2010 \\
& Varietas tahan hama & Bote et al., submitted ; Sauvadet et al., 2019; Mone et al., 2014; Philpott \\
& Pemupukan & \& Armbrecht, 2006; Meno, 2018 \\
& Pemangkasan & Dufour et al., 2019; Bigirimana et al., 2019 \\
& Tanpa pohon penaung & Marino et al., 2015 \\
& Kerapatan kopi & Soto-Pinto et al., 2002 \\
\hline
\end{tabular}


Pada Tabel 2 menunjukkan bahwa agroforestry menjadi perhatian utama di dalam penelitian tentang kopi, terutama yang terkait dengan pengelolaan hama PBKo. Dari 22 artikel yang ditemukan, terdapat 12 artikel yang membahas tentang efek pohon naungan terhadap hama PBKo dan tanaman kopi. Sistem agroforestry kopi dengan jenis pohon penaung bertujuan untuk konservasi biodiversitas (Denu et al., 2017; Rahn et al. 2018; Tschora et al., 2019; Jezeer et al., 2019; Nesper et al., 2017; Bosselmann et al, 2009), dan dapat mengurangi infestasi PBKo (Beilhe et al., 2020). Akan tetapi, Marino et al. (2015) menyatakan bahwa justru infestasi PBKo tertinggi terdapat pada plot pohon penaung (7-52\%) dibandingkan dengan kopi tanpa naungan (4-26\%), sedangkan total populasi PBKo per buah kopi lebih tinggi pada kopi tanpa naungan (suhu yang tinggi dan kelembaban relatif yang rendah) dibandingkan dengan naungan (Morino et al., 2015). Hal ini tergantung pada jenis pohon penaungnya.

Pada kopi yang cenderung diabaikan tanpa adanya penambahan nutrisi, ditemukan sejumlah serangga arthropoda dengan kelimpahan yang terbanyak terdapat pada family Arachnida, Blattaria, Heteroptera dan yang terbanyak di bagian pinggir dibandingkan di tengah (Richter et al., 2007), dan rentan diserang oleh hama (Wang et al., 2015). Tetapi, pada agroforestry yang kompleks (banyaknya strata vegetasi, keragaman dan kelimpahan tanaman, kerapatan tanaman penaung dan semak) dapat memengaruhi jumlah populasi PBKo dan berkorelasi positif dengan karat daun kopi (Soto-Pinto et al.,
2002). Pada tanaman kopi yang tanahnya berada di bawah naungan tanaman Erythrina poepiggiana, dengan pemangkasan yang rutin dan spesies fiksasi $\mathrm{N}_{2}$ dapat meningkatkan ketersediaan nutrisi dan kerapatan fauna (Sauvadet et al., 2019). Persentase tutupan pohon penaung juga berkorelasi positif dengan infestasi PBKo, tetapi berkorelasi negatif dengan fenologi tanaman kopi, dan persentase pohon naungan yang tinggi berkorelasi negatif dengan intensitas kerusakan (Beilhe et al., 2020).

\section{Teknologi Pengendalian Biologis}

Hasil penelusuran menunjukkan bahwa terdapat 31 artikel yang terkait dengan teknologi pengendalian PBKo secara biologis dengan menggunakan musuh alami. Musuh alami yang diketahui dapat mengendalikan hama PBKo pada tanaman kopi adalah parasitoid Cephalonomia stephanoderis, Prorops nasuta dan Phymastichus coffea (Vega et al., 2015; Rodriguez et al., 2017; Infante et al., 2013), semut dan burung, thrips, anoles dan Coleoptera (Jaramillo et al., 2010), laba-laba (Jaramillo et al., 2014), dan nematoda Steinernema carpocapsae (Dufour et al., 2019; Escobar-Ramirez, 2019), Heterorhabditis sp. (Allard \& Moore, 2011), dan Bacillus thuringiensis (Nakai \& Lacey, 2017) (Tabel 3.). Biokontrol terhadap PBKo dipengaruhi juga oleh pengelolaan tanaman pada tingkatan lahan dan oleh struktur lanskap yang berada di sekeliling agroekosistem kopi (Beilhe et al., 2020; Karp et al., 2013).

Tabel 3. Musuh Alami yang ditemukan untuk mengendalikan hama PBKo

\begin{tabular}{|c|c|c|}
\hline Kelompok & Jenis & Penulis \\
\hline \multirow[t]{2}{*}{ Predator } & Semut & $\begin{array}{l}\text { Beilhe et al., 2020; Armbrecht et al., 2007; De la Mora et } \\
\text { al., 2014; Escobar-Ramirez et al., 2019; Milligan et al., } \\
\text { 2016; Morris, Vandemeer \& Perfecto, 2015; Gonthier et } \\
\text { al., } 2013\end{array}$ \\
\hline & Burung & $\begin{array}{l}\text { Gordon et al., 2007; Philpott et al., 2008; Guadarrama et al., } \\
\text { 2019; Escobar-Ramirez et al., 2019; Milligan et al., 2016; } \\
\text { Buechley et al., 2015; Martinez-Salinas et al., } 2016\end{array}$ \\
\hline \multirow[t]{3}{*}{ Parasitoid } & $\begin{array}{l}\text { Tabuhan Cephalonomia } \\
\text { stephanoderis, }\end{array}$ & $\begin{array}{l}\text { Vega et al., 2015; Rodriguez et al., 2017; Infante et al., } \\
\text { 2013; Escobar-Ramirez et al., 2019; Pak et al., 2015; } \\
\text { Lauziere } \text { et al., 1999; Lauziere } \text { et al., } 2000\end{array}$ \\
\hline & Tabuhan Prorops nasuta & $\begin{array}{l}\text { Vega et al., 2015; Rodriguez et al., 2017; Infante et al., } \\
\text { 2013; Escobar-Ramirez et al., 2019; Pak et al., } 2015\end{array}$ \\
\hline & $\begin{array}{l}\text { Tabuhan Phymastichus } \\
\text { coffea }\end{array}$ & $\begin{array}{l}\text { Vega et al., 2015; Rodriguez et al., 2017; Infante et al., } \\
\text { 2013; Escobar-Ramirez et al., 2019; Pak et al., } 2015\end{array}$ \\
\hline \multirow[t]{5}{*}{$\begin{array}{l}\text { Entomopatogen } \\
\text { (Biopestisida) }\end{array}$} & Jamur Beuveria bassiana & $\begin{array}{l}\text { Aristizábal et al., 2016; Beilhe et al., 2020; Escobar- } \\
\text { Ramirez et al., 2019; Moura et al., 2019; Rehner et al., } \\
\text { 2006; Monzon, Guharay \& Klingen, 2008; Costa Mota et } \\
\text { al., 2017; Posada \& Vega, } 2006\end{array}$ \\
\hline & $\begin{array}{l}\text { Jamur } \\
\text { anisopliae }\end{array}$ & $\begin{array}{l}\text { Escobar-Ramirez et al., 2019; Pava-Ripoll et al., 2008; } \\
\text { Moura et al., 2019; }\end{array}$ \\
\hline & $\begin{array}{l}\text { Nematoda Steinernema } \\
\text { carpocapsae }\end{array}$ & Dufour et al., 2019; Escobar-Ramirez et al., 2019 \\
\hline & $\begin{array}{l}\text { Nematoda Heterorhabditis } \\
\text { sp. }\end{array}$ & Allard \& Moore, 2011 \\
\hline & Bacillus thuringiensis & $\begin{array}{l}\text { Nakai \& Lacey, 2017; Lopez-Pazos et al., 2009; Zorzetti et } \\
\text { al., } 2018\end{array}$ \\
\hline
\end{tabular}


Pada Tabel 3. menunjukkan bahwa penelitian mengenai musuh alami pada tanaman kopi sudah banyak dilakukan, dan hampir merata untuk setiap jenis musuh alami, baik yang dilakukan di laboratorium maupun di lapangan. Penelitian mengenai jamur Beauveria bassiana lebih banyak dikaji potensinya dibandingkan dengan musuh alami lainnya. Kajian mengenai mengenai potensi semut dan burung untuk mengendalikan hama PBKo juga cukup banyak dilakukan. Tanaman kopi yang berpenaung dapat meningkatkan keberhasilan dalam pelaksanaan biokontrol dengan menggunakan jamur B. bassiana (Aristizábal et al., 2016; Beilhe et al., 2020), meningkatkan laju predasi oleh semut (Armbrecht et al., 2007; Beilhe et al., 2020) dan meningkatkan keragaman dan kelimpahan musuh alami dari PBKo lainnya, seperti semut (Beilhe et al, 2020) dan burung (Philpott et al., 2008).

Semut Ectatomma ruidun dan E. tuberculatum merupakan predator bagi PBKo yang paling sering ditemui di perkebunan kopi, seperti pada serasah daun, tanah, dan kanopi tanaman kopi. Keragaman semut dapat menimbulkan efek top down yang negatif terhadap PBKo (Beilhe et al., 2020), sehingga semakin beragaman dan berlimpah semut maka layanan predasi akan meningkat, terutama pada skala lokal yang dicirikan dengan kompleksitas vegetasi dan penggunaan pestisida, perpindahan PBKo pada vegetasi yang kompleks akan menurun, tetapi keragaman dan kelimpahan semut akan meningkat (De la Mora et al., 2014). Pohon penaung dapat meningkatkan kelimpahan musuh alami berupa semut, sehingga mengurangi infestasi PBKo (Beilhe et al., 2020). Semut akan menyerang PBKo ketika kerapatannya tinggi (Morris et al., 2015) dan semut menghambat kolonisasi PBKo pada buah kopi (Gonthier et al., 2013). Namun, semut Azteca sericeasur juga dapat menjadi media penyebaran kutu (Coccus sp.) yang kerapatannya tinggi dan menyerang tanaman kopi (Rivera-Salinas et al., 2018).

Burung sebagai salah satu predator bagi PBKo, keragaman dan kelimpahannya dipengaruhi oleh kanopi pohon penaung kopi (shade cover), persentase pohon dengan epifit (percent of trees with epiphytes) dan ketinggian kanopi (canopy height), dan akan menghasilkan keuntungan yang tinggi bagi petani, melalui konservasi biodiversitas (Gordon et al., 2007; Martinez-Salinas, 2016). Sertifikasi dapat meningkatkan konservasi burung sebagai predator hama kopi agar lebih ramah lingkungan (Buechley et al., 2015).

\section{Teknologi Kimiawi}

Hasil penelusuran menunjukkan bahwa terdapat 5 artikel yang terkait dengan teknologi pengendalian hama PBKo secara kimiawi. Senyawa kimiawi yang dimaksud adalah pengendalian hama BPKo secara kimiawi dengan menggunakan pestisida sintetik (Tabel 4.), walaupun saat ini sudah banyak digunakan juga pestisida nabati dan mineral, di antaranya dengan menggunakan minyak nabati dan minyak mineral (Celestino et al., 2016). Minyak nabati yang digunakan adalah minyak kanola, minyak bunga matahari, minyak jagung, minyak kedelai dan minyak kastor atau jarak. Penelitian menunjukkan bahwa minyak jarak dapat menyebabkan kematian terhadap hama betina PBKo sebesar 53,7\%. Akan tetapi, penelitian ini belum cukup memuaskan karena karakteristik dari sebagian besar minyak nabati yang kurang persisten di lingkungan, serta memiliki tingkat pengendalian yang rumit terhadap hama PBKo, karena siklus hidup PBKo yang selalu berada di dalam buah kopi (Vega et al., 2009; Vega et al., 2017).

Tabel 4. Kelompok pestisida yang digunakan untuk mengendalikan PBKo

\begin{tabular}{|c|c|c|c|}
\hline Bahan aktif & Golongan & Organ target & Penulis \\
\hline Cyantraniliprol & Organoklorin & $\begin{array}{l}\text { Jaringan otot } \\
\text { (ryanodine receptor) }\end{array}$ & $\begin{array}{l}\text { Souza et al., 2013; Costa et al., } \\
\text { 2020; }\end{array}$ \\
\hline Endosulfan & Organoklorin & Sistem syaraf & $\begin{array}{l}\text { Souza et al., 2013; Parkin, Brun } \\
\text { \&Sucling, } 1992\end{array}$ \\
\hline Chlorantraniliprol & Tiametoksam/neonikotinoid & Jaringan otot & Plata-Rueda et al., 2019 \\
\hline Diamide & Disulfida & $\begin{array}{l}\text { Ryanodine } \\
\text { receptor/kontraksi } \\
\text { otot }\end{array}$ & Rocha Gonring et al., 2019 \\
\hline
\end{tabular}

Pada Tabel 4. menunjukkan bahwa kajian mengenai penggunaan senyawa kimiawi untuk mengendalikan hama PBKo belum banyak dilakukan, dan di antara kajiannya, pestisida berbahan aktif cyantraniliprol dan endosulfan menjadi perhatian para peneliti. Penggunaan kimia sintetik seperti endosulfan 350EC dan cyantraniliprol $100 \mathrm{OD}$ menjadi pilihan teknik pengendalian hama PBKo yang dianggap paling efisien secara kimiawi (Souza et al., 2013). Endosulfan 350EC yang mengandung senyawa siklodieno klorida ini telah banyak digunakan oleh petani di Brazil dan dapat mematikan PBKo yang ada di dalam buah kopi pada dosis 1,5-2liter/ha, dan cyantraniliprol 100OD pada dosis 1,75-2liter/ha. Chlorantraniliprol dapat menghambat aktivitas perkembangan larva PBKo melalui menurunnya mobilitas, berkurangnya laju respirasi, berubahnya perilaku dan aktivitas lokomotor, sehingga dapat menjadi pengganti endosulfan yang sudah menyebabkan resistensi PBKo (Plata-Rueda et al., 2019). PBKo telah mengalami resistensi juga terhadap endosulfan yang digunakan secara penyemprotan 
(Parkin, Brun \& Suckling, 1992). Resistensi PBKo terhadap beberapa bahan aktif insektisida termasuk cyantraniliprol menjadi kendala di dalam penggunaannya, dan pengelolaan resistensi menjadi sangat diperlukan (Costa et al., 2020).

\section{Teknologi Pascapanen}

Hasil penelusuran menunjukkan bahwa hanya terdapat 1 literatur yang terkait dengan teknologi pengendalian hama PBKo secara sanitasi kebun pascapanen. PBKo yang berada di dalam buah kopi akan terbawa ketika dipanen. Serangga hama, enzim mikroorganisme, suhu, kelembaban relatif, dan kadar air memengaruhi kualitas buah kopi, sehingga hama dikendalikan dengan teknologi tradisional seperti sanitasi kebun. Buah kopi tua dapat menjadi reservoir bagi PBKo ketika musim panen berakhir, dan kepadatan buah dan kelimpahan PBKo terbanyak terdapat pada buah kopi tua di bawah daun pohon, sehingga sanitasi kebun perlu dilakukan (Johnson et al, 2019).

\section{Analisis Keefektifan dan Efisiensi Teknologi Pengendalian Hama PBKo}

Berdasarkan jumlah kajian yang telah dilakukan sejak tahun 1995 sampai 2020, teknologi pengendalian hama PBKo secara biologis merupakan kajian yang paling banyak dilakukan dan paling banyak berkesempatan yang luas untuk terus dikembangkan teknologinya. Hal ini disebabkan oleh karena beberapa kelebihannya, di antaranya: 1) telah tersedia di alam; 2) ramah lingkungan; 3) dapat berkelanjutan; dan 4) lebih murah/ekonomis. Selain itu, pengendalian biologis pada tanaman kopi dianggap aman, ramah lingkungan, dan telah berhasil mengendalikan hama tanaman kopi (Escobar-Ramirez et al., 2019;Jimenez et al., 2019). Walaupun demikian, terdapat beberapa kendala, di antaranya 1) sulit diimplementasikan, sehingga seringkali tidak dimasukan ke dalam portofolio pengendalian hama PBKo; 2) tingkat virulensi atau patogenitasnya rendah; dan 3) masih perlu dikembangkan teknologi yang dapat mendukung penggunaan musuh alami di alam

Jamur B. bassiana (Balsamo) Vuillemin dan jamur lainnya seperti Metarhyzium anisopliae (Metschnikoff) (Moura et al., 2019), dan nematoda Steinernema carpocapsae Weiser and Heterorhabditis spp banyak digunakan sebagai biopestisida dan produknya telah beredar luas di masyarakat dalam bentuk bubuk (wettable powders) namun tidak diformulasi. Akan tetapi, dibandingkan dengan tanaman lainnya, maka produk musuh alami untuk tanaman kopi tergolong masih belum banyak digunakan oleh petani. Dari 750 spesies jamur, 90 genus menjadi patogen bagi serangga yaitu dari famili Chytridiomycota, ascomycota, basidiomycota, dan subfamili entomophthoromycotina (Rajula et al., 2020). Kekurangan dari B. basiana dan M. anisopliae adalah kurangnya virulensi dari jamur entomopatogen, walaupun saat ini terdapat teknologi nuklir yang dapat digunakan untuk meningkatkan patogenitasnya (Rehner et al., 2006; Pava-Ripoll, 2008). Selain itu, B. bassiana jika disemprotkan, daya mortalitasnya rendah terhadap PBKo, sehingga perlu ditambahkan woven fabric (wol) (Costa Mota et al., 2017), dan B. bassiana juga dapat dikembangkan dari bibit kopi yang ditumbuhkan secara invitro (Posada \& Vega, 2006).

Selain itu, musuh alami PBKo sangat dipengaruhi oleh kondisi lingkungan seperti iklim. Perubahan iklim akan memengaruhi proses biologis, fisiologis, perilaku dan penyebaran musuh alami di alam, sehingga menjadi tidak efektif untuk mengendalikan hama PBKo. Dalam konteks perubahan iklim, biodiversitas dapat terancam (Foley et al, 2015; IPCC, 2018; FAO, 2019; Boukal, et al. 2019) dan fungsi layanan ekosistem dapat berubah (Markkula et al., 2019; Kazemi et al, 2019). Perubahan iklim dapat menurunkan dan memusnahkan berbagai spesies di perkebunan kopi. Dari 105.000 spesies yang dipelajari, 6\% dari serangga, $8 \%$ dari tanaman dan $4 \%$ dari vertebrata akan hilang hampir setengahnya akibat kenaikan suhu sebesar $1,5^{\circ} \mathrm{C}$ dan $18 \%$ serangga, $16 \%$ tanaman dan $8 \%$ vertebrata pada kenaikan suhu geografis sebesar $2^{\circ} \mathrm{C}$ (Kagezi, 2019), ditambah dengan adanya kebakaran hutan dan penyebaran spesies invasive dan pengelolaan hama yang tidak tepat. Untuk itu, inovasi teknologi menjadi kebutuhan utama untuk meningkatkan keefektifan dan efisiensi dari teknologi pengendalian secara biologis.

Pengendalian hama PBKo secara kultur teknis terutama dengan sistem agroforestry yang berpenaung, terbukti lebih mudah diterapkan oleh petani, teknologinya tersedia, aman bagi lingkungan dan produk pertanian, berkelanjutan, dan tidak memerlukan biaya yang mahal, sehingga lebih ekonomis. Namun, dalam implementasinya dapat dikombinasikan dengan pengendalian secara biologis, karena terdapat potensi interaksi yang positif antara sistem agroforestry dan sistem biologis yang berlangsung di dalamnya. Selain itu, kondisi ekologis di sistem agroforestry dapat menunjang proses biologis yang terkait dengan pengendalian hama.

\section{Prospek Penelitian Ke depan}

Penelitian mengenai pengelolaan hama PBKo pada tanaman kopi masih terus dikembangkan, dengan tujuan untuk memperoleh suatu inovasi teknologi pengelolaan hama yang efektif dan efisien. Salah satunya adalah dengan menerapkan konsep ekologi lanskap pada skala spasial. Konservasi biodiversitas musuh alami dalam upaya untuk meningkatkan keefektifan pengendalian hama secara biologis masih terus dikembangkan (Jimenez et al., 2019), dengan mempertimbangkan skala spasial dan temporal, yaitu pada area yang lebih luas dan prosesnya dapat berlangsung dalam jangka waktu yang panjang sehingga berkelanjutan (Ravnborg, 
2004; Baker et al., 2020). Monitoring dengan pendekatan biodiversitas hama dan musuh alami pada skala lanskap akan lebih efektif dibandingkan dengan pendekatan pada skala kecil (Altieri \&Nicholls, 2004; Sharma et al, 2014) karena: 1) pada skala lanskap, meningkatnya variable kualitas habitat akan bermanfaat bagi proses ekologis, berupa regulasi hama, musuh alami, organisme bermanfaat lainnya dan vector; dan 2) pergerakan organisme ini akan sangat ditentukan oleh status konektifitas dari suatu lansekap (Avelino et al., 2012).

Masih sedikit kajian mengenai efek lanskap terhadap hama pada tanaman perkebunan (Schmidt Jason M. et al., 2019), terutama pada tanaman tahunan dan hama polifagus (Schmidt et al., 2019). Bahkan, kajian tentang pengelolaan hama dengan menggunakan pendekatan lanskap dalam konteks perubahan iklim pun belum banyak dilakukan (Heeb et al., 2019), terutama pada tanaman kopi arabika di dataran tinggi di Indonesia.

Pengetahuan tentang dinamika populasi hama, interaksi tropik dalam agroekosistem, penggabungan habitat yang dibudidayakan (crop/production area) dan tidak digarap (non crop/semi natural area) di dalam suatu bentang alam/lanskap sebagai kerangka kerja diperlukan untuk menganalisis proses ekologi (Heeb et al., 2019; Brévault \& Clouvel, 2019). Dengan demikian, inovasi teknologi ini berpotensi untuk diterapkan dan dikembangkan di Indonesia.

\section{DAFTAR PUSTAKA}

Allard G, \& Moore D. 2011. Heterorhabditis sp. Nematodes as agents for coffee berry borer, Hypothenemus hampei (Scolytidae). Journal of invertebrate phatology 54:45-48. https://doi. org/10.1016/0022-2011(89)90138-9.

Altieri MA, \& Nicholls C. 2004. Biodiversity and Pest Management in Agroecosystems.

Aristizabal LF, Bustillo AE, \& Arthurs SP. 2016. Strategies from Latin America that could be usefull for coffee farmers in Hawaii. Insects 7(1):6. https://doi.org/10.3390/insects7010006

Avelino J, Romero-Guardan A, Cruz-Cuellar, HF, Declerck F. 2012. Lanscape Context And Scale Differentially Impact Coffee Leaf Rust, Coffee Berry Borer, And Coffee Root-Knot Nematodes. Ecology Apllication 22.pp:584596.https://doi.org/10.1890/11-0869.1.

Badan Pusat Statistik. 2018. Statistik Indonesia. https://www.bps.go.id/publication/2018/07/03/ 5a963c1ea9b0fed6497d0845/statistikindonesia-2018.html.

Baker BP, Green TA, Loker AJ. 2020. Biological Control And Integrated Pest Management In Organic And Convensional Systems. Biological Control 140:104095.https://doi.org /10.1016/j.biocontrol.2019.104095.

Beilhe LB, Roudine S, Perez JAQ, Allinne C, Daout D, Mauxion R, \& Carval D. 2020. Pestregulating networks of the coffee berry borer
(Hypothenemus hampei) in agroforestry systems. Crop protection 131:105036.https:// doi.org/10.1016/j.cropro.2019.105036.

Bigirimana, J, Adam CG, Ggatarayiha CM, Muhutu JC, \& Gut LJ. 2019. Occurrence of potato taste defect on coffee and its relations with management practices in Rwanda. Agriculture, ecosystem and environment 269:8287.https://doi.org/10.1016/j.agee.2018.09.022.

Boukal, DS, Bideault A, Carreira BM, \& Sentin A. 2019. Species Interaction Under Climate Change: Connecting Kinetic Effects Of Temperature On Individuals To Community Dynamics. Current opnion in Insect Science 35.pp:88-95.http://doi.org/10.1016/j.cois.2019. 06.014 .

Bosselmann, AS, Dons K, Oberthur T, Olsen CS, Raebild A, \& Usma H. 2009. The influence of shade trees on coffee production in small holder coffee agroforestry systems in southern colombia. Agricultura, ecosystem and environment 129:253-260.https://doi.org/10. 1016/j.agee.2008.09.004.

Brevault T. \& Clouvel P. 2019. Pest Management: Reconciling Farming Practices and Natural Regulation. Crop Protection 115:1-6.

Buechley ER, Sekercioglu CH, Atickem A, Gebremichaen G, Ndungu JK, Mahamued BA, Beyene T, Mekonnen T, \& Lens L. 2015. Importance of Ethiopian shade coffee farms for forest bird conservation. Biological conservation 188:50-60.https://doi.org/10.101 6/j.biocon.2015.01.011.

Castillo JM, Casas J, \& Romero E. 2011. Isolation of an endosulfan-degrading bacterium from a coffee farm soil: persistence and inhibitory effects on its biological functions. Scince of the total environment 412-413:20-27.https:// doi.org/10.1016/j.scitotenv.2011.09.062.

Costa NCR, Picelli ECM, Silva FMA, Gonring AHR, Guedes RNC, Durigan MR, \& Fernandes FL. 2020. Cyantraniliprole susceptability baseline, resistance survey and control failure likelihood in the coffee berry borer Hypothenemus hampei. Ecotoxicology and environmental safety 203:110947.https://doi.org/10.1016/ j.ec oenv.2020.110947.

Mota LHC, Silva WD, Sermarini R.A, Demetrio CGB, Bento JMS, Delalibera-Jr I. 2017. Autoinoculation trap for management of Hypothenemus hampei (Ferrari) with Beauveria bassiana (Bals.) in coffee crops. Biological control 111:32-39.https://doi.org/ 10.1016/j.biocontrol.2017.05.007.

Celestino FN, Pratissoli D, Machado LC, Goncalves, SJHJ, Vagner TQ \& Mardgan, L. 2016. Control of coffee berry borer, Hypothenemus hampei (Ferrari) (Coleoptera: Curculionidae: Scolitinae) with botanical insecticides and 
mineral oils. Acta Scientiarum. Agronomy Maringa, 38(1):1-8.

De la Mora A, Garcia-Ballinas JA, \& Philpott SM. 2015. Local, landscape and diversity driver of predation services provided by ants in a coffee landscape in Chiapas, Mexico. Agriculture, ecosystem and environment 201:8391.https://doi.org/10.1016/j.agee.2014.11.006.

Denu D, Platts PJ, Kelbessa E, Gole TW, \& Marchant R. 2016. The role of traditional coffee management in forest conservation and carbon storage in the Jimma Highlands, Ethiopia. Forest Trees Livelihoods 25(3):226-238.

Direktorat Jendral Perkebunan. 2017. Pengenalan dan Pengendalian Organisme Pengganggu Tumbuhan (OPT) Tanaman Kopi. Direktorat Perlindungan Perkebunan, Kementerian Pertanian.

Direktorat Jendral Perkebunan. 2019. Outlock 2017 Komoditas pertanian sub sektor perkebunan kopi. Kementerian Pertanian. Jakarta.

Dufour BP, Kerana IW, \& Ribeyre F. 2019. Effect of coffee tree pruning on berry production and coffee berry borer infestation in the Toba Highlands (North Sumatra). Crop Protection 122:151-158. https://doi.org/10.1016/j.cropro. 2019,05.003.

Escobar-Ramirez S, Grass I, Armbrecht I, \& Tscharntke T. 2019. Biological control of the coffee berry borer: main natural enemies, control success and landscape influence. Biological control 136:103992.https://doi.org/ 10.1016/j.biocontrol.2019.05.011.

Foley JA, DeFries R, Asner GP, Barford C, Bonan G, \& Carperter SR. et al. 2005. Global Concequences Of Land Use. Science 309.pp: 570-574.

Food and Agriculture Organization._2017. Integrated pest management of major pest and diseases in Eastern Europe and The Caucasus._ISBN 97892-5-109144-9.

Gonthier DJ. Ennis KK, Philpott SM, Vandemeer J, \& Perfecto I. 2013. Ants defend coffee from berry borer colonization. Biocontrol 58:815820.

Gordon C, Manson R, Sundberg J, \& Cruz-Angon A. 2007. Biodiversity, profitability and vegetation structure in a Mexican coffee agroecosystem. Agriculture, ecosystem and environment 118:256-266.https://doi.org/10.1016/j.agee.20 06.05.023.

Guadarrama, AC, Martinez- Salinas A, N. Aristizabal, \& Ricketts TH. 2019. Ecosystem services by birds and bees in coffee in a changing climate: a review of coffee berry borer control and pollination. Agriculture, ecosystem and environment 280:53-67.https://doi.org/10. 1016/j.agee.2019.04.011.

Hayyun DA, Megantara EN, \& Parikesit. 2018. Kajian layanan ekosistem pada sistem agroforestry berbasisi kopi di Desa Cisero, Garut. Jurnal Pengelolaan Lingkungan Berkelanjutan 2(3). https://doi.org/10.36813/ jplb.2.3.200-219.

Heeb L. Jenner E, \& Cock MJW. 2019. Climate Smart Pest Management: Building Resilience of Farms and Landscape to Changing Pest Threath. Journal of Pest Science.doi:10.1007/s10340-019-01083-y.

Infante F, Castillo A, Perez J, \& Vega FE. 2013. Field-cage evaluation of the parasitoid Phymastichus coffea as a natural enemies of coffee berry borer, Hypothenemus hampei. Biological control 67:446-450. https://doi.org /10.1016/j.biocontrol.2013.09.019.

Intergovermental Panel on Climate Change. 2018. Global Warming of $1.5^{\circ} \mathrm{C}$. Summary for Policymaker. ISBN 978-92-9169-151-7.

Iverson AL, Gonthier DJ, Pak D, Ennis KK, Burnham RJ, Perfecto I, Rodriguez MR, \& Vandermeer JH. 2019. A multifunctinal approach for achieving simultaneous biodiversity conservation and farmer livelihood in coffee agroecosystem. Biological conservation 238:108179.https://doi.org/10.1016/j.biocon.20 19.07.024

Jaramillo J, Borgemeister C, \& Baker P. 2006. Coffee berry borer Hypothenemus hampei (Coleoptera:Curculionidae): Searching for sustainable control strategies. In buletin of entomology research $96 \quad$ (3):223233.doi:https://doi.org/10.1079/BER2006434.

Jaramillo CR, Santos RHS, Martinez HEP, Cecon PR., \& Fardin MP. 2010. Produsction and vegetative growth of coffee trees under fertilization and shade levels. Scientia Agricola 67: 639-645.

Jezeer RE, Santos MJ, Verweij PA, Boot RGA, \& Clough Y. 2019. Benefits for multiple ecosystem services in Peruvian coffee agroforestry system without reducing yield. Ecosystem services 40:101033. https://doi.org/ 10.1016/j.ecoser.2019.101033.

Jimenez-Garcia L, Garcia-Martinez YG, Marco MV, Perez MI, \& Jimenez-Garcia D. 2019. Biodiversity Analysis of Natural Arthropoda Enemies in Vineyard Agroecosystems in La Rioja, Spain. Journal of Asia-Pasific Entomology 22: 308-315. https://doi.org/10. 1016/j.aspen.2019.01.008.

Johnson, MA, Fortna S, Hollingsworth RG, \& Manoukis NC. 2019. Postharvest population reservoirs of coffee berry borer (Coleoptera:Curculionidae) on Hawaii Island. Journal of economic Entomology 122(6):28332841.https://doi.org/10.1093/jee/toz219.

Kagezi. 2019 Kagezi. H.Godfrey, Kucel Patrick, Kobusinge Judith, Olango D.Nicholas, Nakibuule Lilian, Wagoire, W.William. 2018. Predicting The Respon Of Insect Pests And 
Diseases Of Arabica Coffee To Climate Change Along An Altitudinal Gradient In Mt.Elgon Region, Uganda. Journal of Agriculture and Environmental Science 7: 134140. doi: 10.15640/jaes.v7n1a14.

Karp. 2013. Karp DS., C. Kramer, R Meehan TD, Martin EA, Del Clerde F. Grab H....Martinez Salinas A. 2018. Crop Pests And Predators Exhibit Inconsistent Responses to Surrounding Landscape Composition. Proceeding of the National Academic of Science of the United State of America 115: E7863-E7870. doi:10.1073/pnas.1800042115.

Kazemi H, Klug H, \& Kamkar B. 2018. New Services and Roles of Biodiversity In Modern Agroecosystems: A Review. Ecological indicators 93:1126-1135.https://doi.org/10.101 6/j.ecolind.2018.06.018.

Kementerian Pertanian Republik Indonesia. 2015. Outlook Kopi 2015. Portal Epublikasi Pertanian, Kementerian Pertanian Republik Indonesia.

Lauziere I, Perez-Lachaud G, \& Brodeur J. 1999. Influence of host density on the reproductive strategy of Cephalonomia stephanoderis, a parasitoid of the coffee berry borer. Entomologia experimentalis et applicata 92 (1).https://doi.org/10.1046/j.1570-7458.1999. 00520.x.

Lauziere I, Perez-Lachaud G, \& Brodeur J. 2000. Behavior and activity pattern of Cephalonomia stephanoderis (Hymenoptera:Bethylidae) attacking the coffee berry bores, Hypothenemus hampei (Coleoptera: Curculinoidae, Scolytidae). Journal of insect behavior 13:375-395.

Lopez-Pazos SA, J. E.C. Gomez JEC, \& Salamanca JAC. 2009. Cry1B and Cry3A are active against Hypothemenus hampei Ferrari (Coleoptera:Scolytidae). Journal of invertebrate pathology 101(3):242245.https://doi.org/10.1016/j.jip.2009.05.011.

Markkula I, Turunen M, \& Rasmus S. 2019. A Review of Climate Change Impact on A Ecosystem Services In The Sammi Homeland In Finland. Science of the Total Environment 692:1070-1085.http://doi.org/10.1016/j. scitotenv.2019.07.272.

Marino YA, Perez ME, Gallardo F, Trifilio M, Cruz M, \& Beyman P. 2015. Sun vs shade affects infestation, total population and sex ratio of the coffee berry borer (Hypothenemus hampei) in Puerto Rico. Agriculture, ecosystem and environment 222:258-266.https://doi.org/10. 1016/j.agee.2015.12.031.

Martinez-Salinas A, DeClerck F, Vierling K, Vierling L, Legal L, Mendoza SV, \& Avelino J. 2016. Bird functional diversity support pest control services in a Costa Rican coffee farm. Agriculture, ecosystem and environment
235:277-288. https://doi.org/10.1016/j.agee. 2016.10.029.

Milligan MC, Johnson M, Garfinkel M, Smith C, \& Njoroge P. 2016. Quantifying pest control services by birds and ants in Kenyan coffee farms. Biological cinservation 194:58-65 https://doi.org/10.1016/j.biocon.2015.11.028.

Moguel P, \& Toledo VM. 2001. Biodiversity conservation in traditional coffee system in Mexico. Conservation Biology 13. https://doi.org/10.1046/j.1523-1739.1999. 97153.x.

Molina D, Zamora H, \& Blanco-Labra A. 2010. An inhibitor from Lupinus bogotensis seeds effective against aspartic proteases from Hypothenemus hampei. Phytochemistry 71(89):923-929.https://doi.org/10.1016/j.phytoche m.2010.03.006.

Mone S, Kusha KM, Jathanna D, Ali M, \& Goel A. 2014. Comparison of insect biodiversity between organic and conventional plantation in Kodagu, Karnataka, India. Journal of threated taxa 6. https://doi.org/10.11609/JoTT.o3778. 6186-94.

Monzon AJ, Guharay F, \& Klingen I. 2008. Natural occurrence of Beauveria bassiana in Hypothenemus hampei (Coleoptera: Curculionidae) populations in unsprayed coffee fields. Journal of invertebratae pathology 97(2):134-141.https://doi.org/10. 1016/j.jip.2007.07.008.

Morris JR, Vandemeer J, \& Perfecto I. 2015. A keystone ant species provides robust biological control of the coffee berry borer under varying pest densities. PlosOne. https://doi.org/ 10.1371/journal.pone.0142850.

Nakai M, \& Lacey LA. 2017. Chapter 15-Microbial control of insect pest of tea and coffee. Microbial control of insect and mites pests:223-235.https://doi.org/10.1016/B978-012-803527-6.00015-9.

Nesper M, Kueffer C, Krishnan S, Kushalappa CG, \& Ghazoul J. 2017. Shade tree diversity enhances coffee production and quality in agroforestry systems in western ghats. Agriculture, ecosystem and environment 247:172-181. https://doi.org/10.1016/j.agee.2017.06.024.

Ozuna C, Mulik S, Rodriguez BV, Juarez MDRA, \& Lopez CLF. 2020. The effect of organic farming on total phenol, total flavonoids, brown compounds and antioxidant activity of spent coffee grounds from Mexico. Biological agriculture and horticulture: An international journal for sustainable production system 36(2):107-118. https://doi.org/10.1080/0144 8765.2019.1704876.

Pak D, Iverson AL, Ennis KK, Gonthier DJ, \& Vandemeer JH. 2015. Parasitoid wasps benefit from shade tree shade and landscape complexity in Mexican coffee agroecosystems. 
Agriculture, ecosystem, environment 206: 21 32. https://doi.org/10.1016/j.agee.2015.03.017.

Parkin CS, Brun LO, \& Suckling DM. 1992. Spray deposition in relation to endosulfan resistance in coffee berry borer (Hypothenemus hampei) (Coleoptera:Scolitidae) in New Caledonia . Crop protection 11(3):213-220. https://doi.org/ 10.1016/0261-2194(92)90 039-8.

Pava-Ripoll M, Posada FJ, Momen B, Wang C, \& Leger RSt. 2008. Increased pathogenicity against coffee berry borer, Hypothenemus hampei (Coleoptera:Curculionidae) by Metarzhium anisopliae expressing the scorpion toxin (AaIT) gene. Journal of invertebrate pathology 99(2):220-226.https://doi.org/10. 1016/j.jip.2008.05.004.

Perfecto I, Rice RA, Greenberg R, \& Van der Voort ME. 1996. Shade coffee: a dissapearing refuge for biodiversity: shade coffee plantation can contain as much biodiversity as forest habitat. BioScience 46:598-608. https://doi.org/10. 2307/1312989.

Perfecto I, Vandermeer J, Hanson P, \& Cartin V. 1997. Arthropod biodiversity loss and the transformation of a tropical agro-ecosystem. Biodiversity \& Conservation 6:935-945.

Perfecto I, \& Armbrecht I. 2003. Litter-twig dwelling ant species richness and predation potential within a forest fragment and neighboring coffee plantation of contrasting habitat quality in Mexico. Agriculture, ecosystem and environment 97:107-115.https://doi.org/10. 1016/S0167-8809(03)00128-2.

Philpott SM, \& Armbrecht I. 2006. Biodiversity in tropical agroforests and the ecological role of ant diversity in predator function. Ecological entomology 31. https://doi.irg/10.1111/j.13652311.2006.00793.x.

Philpott SM, \& Armbrecht I. 2006. Biodiversity in tropical agroforests and the ecological role of ant diversity in predator function. Ecological entomology 31. https://doi.irg/10.1111/j.13652311.2006.00793.x.

Plata-Rueda A, Martinez LC, Costa NCR, Zanuncio JC, de Sena Fernandes ME, Serrao JE, Guedes RNC, \& Fernandes FL. 2019. Chlorantraniliprole-mediated effects on survival, walking abilities, and respiratory the coffee berry borer, Hypothenemus hampei. Ecotoxicology and environment 172:53-58. https://doi.org/10.1016/j.ecoenv.2019.01.063.

Posada F, \& Vega FE. 2006. Inoculation and colonization of coffee seedlings (Coffea arabica L.) with the fungal entomopathogen Beauveria bassiana (Ascomycota: Hypocreales). Mycoscience 47(5):284-289. https://doi.org/10.1007/S10267-006-0308-6.

Rhan E, Liebig T, Ghazoul J, van Asten P, Laderach P, Vaast P, Sarmiento A, Garcia C, \& Jarsogne L. 2018. Opportunities for Sustainable
Intensification of Coffee Agroecosystem Along an Altitudinal Gradient on MT.Elgon, Uganda. Agriculture, Ecosystem and Environment 263: 31-40. http://doi.org/10.1016/j.agee.2018.04 019.

Rao GVR, Kumari BR, Sahrawat KL, \& Wani SP. 2015. Integrated pest management (IPM) for reducing pesticide residues in crops and natural resources. New horizons in insect science: towards sustainable pest management. Publisher: Springer India. http://dx.doi.org/ 10.1007/978-81-322-2089-3_35.

Rajula J, Rahman A, \& Krutmuang P. 2020. Entomophatogenic fungi in southeast asia and africa and their possible adoption in biological control.Biological control 151:104399.https:// doi.org/10.1016/j.biocontrol.2020.104399.

Ravnborg HM. 2004. Collective action and property rights for sustainable development: Collective action in pest management. 2020 vision for food, agriculture and the environment. International Food Policy Research Institute.

Rehner SA, Posada F, Buckley EP, Infante F, Castillo A, \& Vega FE. 2006. Phylogenetic origins of African and Neotropical Beauveria bassiana s.l. pathogens of the coffee berry borer, Hypothenemus hampei. Journal of invertebrate pathology 93:11-21. https://doi.org/10.1016/ j.jip.2006.04.005.

Reyes EIM, Farias ES, Silva EMP, Filomeno CA, Plata MAB, Picanco MC, \& Barbosa LCA. 2018. Eucalyptus resinifera essensial oils have fumigant and repellent action against Hypothenemus hampei. Crop protection 116:49-55. https://doi.org/10.1016/j.cropro. 2018.09.018.

Richter A, Klein AM, Tscharntke T, \& Tylianakis JM. 2007. Abandonement of Coffee Agroforest Increases Insect Abundance and Diversity. Agroforestry System 69: 175-182.doi:10.1007/ s10457-006.9020-y.

Rivera S, Saraeny I, Forooshani ZH, Soto EJ, Rodriguez JAC, \& Philpott SM. 2018. High intermediary mutualist density provides consistent biological control in a tripatrite mutualism. Biological control 118:26-31. https://doi.org/10.1016/j.biocontrol.2017.12.00 2.

Robinson WA, Ruedy R, \& Hansen JE. 2002. General circulation model simulations of recent cooling in the east-central United States. J. Geophys. Res., 107, no. D24, 4748, doi:10.1029 / 2001JD001577.

Rodriguez D, Cure JR, Gutierrez AP, \& Cotes JM. 2017. A coffee agroecosystem model: III. Parasitoid of the coffee berry borer (Hypothenemus hampei) Ecological Modelling 363:96-110.https://doi.org/10.1016/j.ecomodel. 2017.08.008. 
Rocha G, Henrique A, Silva FMA, Picelli ECM, Plata-Rueda RA, Gorri JER, \& Fernandes FL. 2019. Comparative bioassay methods to determine diamide susceptability for two coffee pest. Crop Protection 121:34-38. https://doi.org/10.1016/j.cropro.2019.03.010.

Sauvadet M, Meersche KVD, Allinne C, Gay F, Filho DMVF, Chauvat M, Becquer T, Tixier P, \& Harmand JM. 2019. Shade Trees have Higher Impact on Soil Nutrient Availablility and Food Web in Organic than Conventonal Coffee Agroforestry. Science of The Total Environment 649:1064-1074. https://doi.org/ 10.1016/j.scitotenv,2018.08.291

Schmidt JM, Whitehouse T, Green K, Krehenwin-Kel H, Schmidt-Jeffris R, \& Sial AA. 2019. Local And Landscape Scale Heterogeneity Shape Spotted Wing Drosophila (Drosophilla suzukii) Activity And Natural Enemy Abundance: Implications For Trophic Interactions. Agriculture Ecosystem and Environment 272:86-94.http://doi,org/10.1016/j.agee.2018. 11.014 .

Simon-Gruita, A. 2019. Genetic Engineering in Coffee. Caffeinated and Cocoa Based Beverages: The Science of Beverages. Cambridge, United Kingdom: Woodhead publishing. v.8, p.447-488.

Sharma HC, \& Prabhakar CS. 2014. Chapter 2. Impact Of Climate Change On Pest Management And Food Security. Integrated Pest Management: current concepts and ecological perspective :23-36. https://doi.org/10.1016/B.978-0-12-3985293.00003-8.

Soto-Pinto L, Perfecto I, Caballero-Nieto J. 2002. Shade over coffee: its effects on berry borer, leaf rust, and spontaneous herbs in Chiapas, Mexico. Agroforestry systems 55:37-45.

Souza HND, Goede, RGMD, Brussaard L, Cardoso IM, Duarte EMG, Fernandes RBA, \& Gomes LC. and Pulleman, M.M. 2012. Protective shade, tree diversity and soil properties in coffee agroforestry systems in the Atlantic Rainforest biome. Agriculture, Ecosystems \& Environment, 146(1), pp. 179-196.

Syakir M \& Surmaini E. 2017. Perubahan Iklim dalam Konteks Sistem Produksi dan Pengembangan Kopi di Indonesia. Jurnal Penelitian dan Pengembangan Pertanian 36(2):77-90.

Queiroz VT, Azevedo MM, Quadros IPS, Costa AV, Amaral AA, Santos GMADA, Juvanhol RS, Telles LAA, \& Santos AR. 2018. Environmental risk assesssment for sustainable pesticide use in coffee production. Journal of contaminant hydrology 219:18-27. https://doi.org/10.1016/j.jconhyd,2018.08.008.

schora, H. \& Cherubini, F. 2020. Co-benefits and trade-offs of agroforestry for climate change mitigation and other sustainability goals in West Africa', Global Ecology and Conservation, 22 (15)

Vega FE, Brown SM, Chen H, Shen E, Nair MB, Ceja-Navarro JA, Brodie EL, Infante F, Dowd PF, \& Pain A. 2015. Draft genome of the most devastating insect pest of coffee worldwide: the coffee berry borer Hypothenemus hampei. Scientific report 5:12525.doi:10.1038/srep 12525.

Wang N, Jassogne L, van Asten PJA, Mukasa D, Wanyama I, Kagezi G, \& Giller KE. 2015. Evaluating coffee yield gaps and important biotic, abiotic, and management factor limiting coffee production in Uganda. European Journal of Agronomy 63:1-11.https://doi.org/10.1016 /j.eja.2014.11.003.

Zorzetti J, Ricietto APS, Pazion FAP, Meneghin AM, Neves PMOJ, Vilas-Boas LA, \& Vilas-Boas GT. 2018. Isolation, morphological and molecular characterization of Bacillus thuringiensis against Hypothenemus hampei Ferrari (Coleoptera:Curculionidae:Scolytidae). Revista Brasileira de Entomologia 62(3):198204.https://doi.org/10.1016/j.rbe.2018.07.002

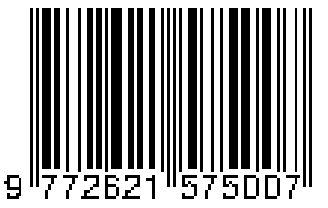

